\title{
Surveillance for Newcastle Disease Virus, Avian Influenza Virus and Mycoplasma Gallisepticum in Wild Birds Near Commercial Poultry Farms Surrounded by Atlantic Rainforest Remnants, Southeastern Brazil
}

-Author(s)

\section{Guimarães MB \\ Hurtado R" \\ Bello CPI \\ Vanstreels RET \\ Ferreira AJP'}

Department of Pathology and IIDepartment of Preventive Medicine and Animal Health, School of Veterinary Medicine and Animal Health, University of São Paulo

\section{-Mail Address}

Corresponding author e-mail address Antonio J. Piantino Ferreira

Av. Prof. Dr. Orlando de Marques Paiva, 87 CEP: 05586-060, São Paulo, SP, Brazil

Tel: $\quad+55113091-1352$

Fax: $\quad+55113091-7829$

Email: ajpferr@usp.br

\section{-Keywords}

Surveillance, Atlantic rainforest, poultry farms, wild birds, Influenza virus, Newcastle disease virus, Mycoplasma gallisepticum.

\section{ABSTRACT}

The geographic overlap between areas of Atlantic rainforest and human activities allows interactions to occur between humans and wild and domestic animals. Despite the great importance of the domestic animal-wildlife-human interface that occurs at poultry farms in terms of public health, economic production and wildlife conservation, there are few studies in Brazil examining the distribution and health of wild birds that interact with poultry farms. From January to December 2010, mist nets were used to capture 166 free-ranging birds that were within close proximity to three poultry farms in Atlantic rainforest remnants in southeastern Brazil. The species composition was examined, and molecular methods were used to test for avian influenza virus, Newcastle disease virus, and Mycoplasma gallisepticum. The avian communities near the poultry farms were dominated by three synanthropic species, which corresponded to $70 \%$ of all captured individuals: house sparrows Passer domesticus (33\%), saffron finches (Sicalis flaveola) (22\%), and ruddy ground-doves (Columbina talpacoti) (15\%). These predominant bird species were in poor body condition $(27 \%)$, were infested with feather mites (43\%), or presented both conditions (23\%). No evidence of infection by avian influenza virus, Newcastle disease virus or $M$. gallisepticum was identified in any of the studied birds. Although no evidence of the studied pathogens was, our findings demonstrate that differences in the environmental characteristics and biosecurity practices influence the wild bird community near poultry farms, which in turn may affect the health status of these synanthropic birds and strengthen their role in the transmission of pathogens.

\section{INTRODUCTION}

The Atlantic rainforest is the second largest forest in South America. Despite being considered a biodiversity hotspot and exhibiting extremely high levels of endemism, only $7 \%$ of this rainforest remains, and it is the most endangered biome in Brazil (Myers et al., 2000). The Brazilian human population has historically been concentrated along the coast, and more than $60 \%$ of the country's population occupies areas originally covered by the Atlantic rainforest (Dean 1995; Tabarelli et al., 2005). The greatest threat to the conservation of this biome is habitat destruction, including destruction due to direct human occupation and to agricultural and livestock production, including poultry production. As a result, rich avian biodiversity $(1,020$ species, out of which 188 are endemic) of this biome is threatened, as much of it is located within close proximity to human and poultry populations (SOS Mata Atlântica, 2012).

Brazil is widely recognised as one of the world's largest poultry producers. It is the largest chicken meat exporter in the world and the third largest broiler producer (UBABEF 2011). Brazil's annual production reached 10.9 million tons of chicken meat in 2009, and it is estimated 
that by $2020,48.1 \%$ of the world's poultry exports will be from Brazil (MAPA 2011). Under this scenario of rapid expansion, the interactions between poultry farms and the avian communities of the Atlantic rainforest have steadily increased.

The geographic overlap between areas of Atlantic rainforest and human activities results in a permanent interface for the interaction of wild birds, poultry and humans, thereby increasing the possibility of the emergence of zoonotic pathogens. Recent and severe outbreaks of H5N1 avian influenza in Asia are thought to have resulted directly from transmission of the virus from wild birds to domestic poultry and then to humans (WHO 2003). Newcastle disease, avian influenza and $M$. gallisepticum infections are significant diseases in poultry industry (Scherer et al., 2011; Kleven, 2008). No outbreaks of these diseases have occurred in Brazil, and these pathogens have not yet been demonstrated to be directly associated with the wildlife-poultry interface in poultry farms (Bueno et al., 1977; MS, 2004; MAPA, 2011). Newcastle disease and avian influenza are particularly relevant not only because they may cause significant economic impacts, but also because they are potentially zoonotic and may be transmitted to humans via either inhalation or ingestion of contaminated food or water (Ley 2003; Webby \& Webster 2003; Jones 2009). On the other hand, infections by Mycoplasma gallisepticum (Mg) can lead to significant economic losses in the poultry industry, and although this pathogen seldom leads to widespread avian mortality, it considerably decreases production indexes and carcass yields (Ley, 2003; Cardoso et al., 2006).

In this study we examine the species composition of wild bird populations in areas in close proximity to poultry farms and to Atlantic forest remnants in southeastern Brazil, to evaluate their general health status, and to try to detect the presence of NDV, AIV and $\mathrm{Mg}$.

\section{MATERIAL AND METHODS}

\section{Study locations}

Three farms were studied in the municipalities of

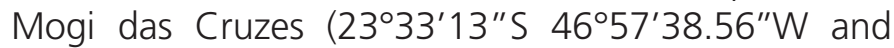

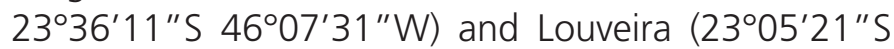
$46^{\circ} 57^{\prime} 39^{\prime \prime} \mathrm{W}$ ) in São Paulo state, southeastern Brazil (Figs. 1 and 2, Table 1). The farms are located in a heavily human-impacted landscape (between 543 and 675 inhabitants per $\mathrm{km}^{2}$ ), composed of a mosaic of Atlantic rainforest (submontane dense tropical rainforest). The mean temperature in the region is $26.2^{\circ} \mathrm{C}$, and the mean annual rainfall is $1400 \mathrm{~mm}$ (CEPAGRI 2012).

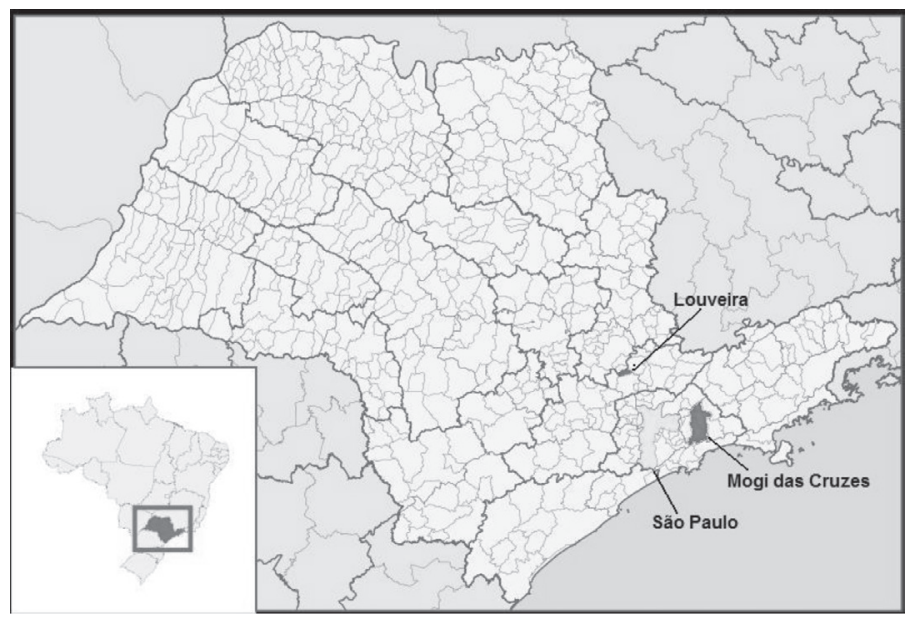

Figure 1 - The cities of Louveira and Mogi das Cruzes in São Paulo State, Brazil.

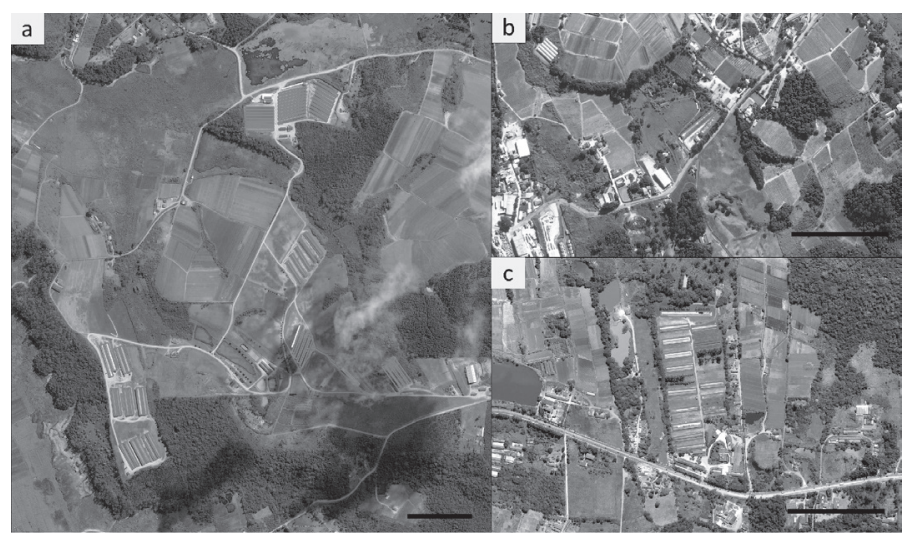

Figure 2 - Satellite images of the studied poultry farms illustrating the surrounding landscape. Red rectangles identify the poultry facilities, yellow lines identify the mist nets used for bird capture. The black bars measure 250 meters. Source: SPOT Image.

Farm 1 was a breeding farm with approximately 70,000 birds, applied good production practices (e.g., intense biosecurity controls, routine vaccinations, facilities protected by nets to prevent the entry of free-ranging birds) and was separated by a 1,000 m clear-cut radius from nearby agricultural areas and degraded Atlantic rainforest fragments. Farm 2 was an egg-laying farm with approximately 550,000 birds. The landscape surrounding Farm 2 was composed mostly of pine tree and eucalyptus reforestation areas, with small patches of Atlantic rainforest. Farm 2 was within $5 \mathrm{~km}$ from a wild-bird release area (Barragem Ponte Nova), where wild birds seized by environmental authorities are regularly released as part of a population supplementation program. Farm 3 was a broiler farm with two houses with approximately 10,000 and 15,000 birds each. Farm 3 was surrounded by heavily degraded fragments of Atlantic rainforest. Farms 2 and 3 were both open and had no control measures to prevent free-ranging birds from entering. 
Table 1 - Characteristics of the poultry farms used in this studied.

\begin{tabular}{lccc}
\hline & Farm 1 & Farm 2 & Farm 3 \\
\hline Production activity & breeders & egg-laying hens & broilers \\
Biosecurity level & high & Low & low \\
Sampling season & autumn & spring/summer & winter \\
Approximate flock size (animals) & 70,000 & 550,000 & 25,000 \\
Proximity to wild bird release area & no & yes & no \\
\hline
\end{tabular}

\section{Bird capture and sample collection}

All captures and procedures were authorised by Instituto Chico Mendes de Conservação da Biodiversidade (SISBIO permission 20171-1) and the Committee of Ethics on Animal Use of São Paulo University (Comitê de Ética no Uso de Animais da Universidade de São Paulo, CEUA-USP, authorization 1797).

Mist nets were used to capture free-ranging birds near the three poultry farms: Farm 1, on four sampling days between and to May 2010; Farm 2, on four days in June 2010; and Farm 3, on five days in July, August, and December 2010. Mist nets were placed at 2 to $10 \mathrm{~m}$ from the poultry facilities on Farms 2 and 3; however, for Farm 1, the mist nets had to be set 100 $m$ away from the facilities. On each sampling day, four mist nets $(7 \times 3 \mathrm{~m})$ were mounted and surveyed every 30 min from 06:00 to $12: 00 \mathrm{~h}$.

Birds were identified using aluminium leg bands, weighed, and examined to determine their body condition according to pectoral muscle size (poor, normal, or good - adapted from IBAMA, 1994); moulting status (moulting or not moulting); ectoparasites (presence or absence); and body lesions (presence or absence). Sterile cotton swabs were used to collect oropharyngeal and cloacal samples from each bird. Swabs for virology analyses were placed in sterile cryotubes containing $500 \mu \mathrm{L}$ of transport media (5\% glycerol in phosphate buffered saline with penicillin and amphotericin B), immediately frozen in liquid nitrogen $\left(-196{ }^{\circ} \mathrm{C}\right)$, and transported to the laboratory, where they were stored in a freezer (-80 $\left.{ }^{\circ} \mathrm{C}\right)$ until processing. The swabs were placed in sterile chemistry tubes containing $1,000 \mu \mathrm{L}$ of Frey liquid media and stored at $37^{\circ} \mathrm{C}$ for 24 hours.

\section{Laboratory procedures}

DNA was extracted using the boiling method (Nascimento et al., 1991), and RNA was extracted using Brazol $®$ (LGC Biotecnologia Ltda., Brazil) following the manufacturer's instructions. A published PCR protocol was employed to detect the DNA of Mycoplasma gallisepticum (Nascimento et al., 1991). Published RT-
PCR protocols for RNA reverse transcription and amplification using the One-Step RT-PCR Kit $®$ (Qiagen, São Paulo, Brazil) were applied for the diagnosis of Newcastle Disease Virus (Pang et al., 2002) and Influenza A Virus (Poddar 2002). All reactions were repeated separately at least twice. A positive control (provided by Dr. Edison Durigon from the Biomedical Sciences Institute of the University of São Paulo) and negative controls (sterile water) were included for all reactions. The amplification products were analysed by electrophoresis in 1.5\% agarose gel containing Blue Green Dye (LGC, São Paulo, Brazil). A 100 bp DNA Ladder (Invitrogen Corp., Carlsbad, CA, USA) was used as the size marker.

\section{Statistical analyses}

The apparent abundance was calculated as the total number of individuals captured on a farm divided by the total sampling days at that location. Species richness $(S)$ refers to the total number of species recorded on a farm. Shannon's diversity index $\left(H^{\prime}\right)$ is a well-recognised indicator of species diversity and equitability in avian communities and was calculated according to Tramer (1969). The Kruskal-Wallis test was performed to compare the apparent abundances among farms. The Chi-Squared test was used to compare farms relative to the following characteristics of each of the two most frequent species: body condition and presence of feather mites. The Kruskal-Wallis test was applied to compare farms for total number of individuals and apparent abundance (SPSS Inc., Chicago, IL, USA). The adopted significance level (alpha) was 0.05 for all tests.

\section{RESULTS}

On several occasions, free-ranging birds were directly observed entering the poultry facilities on Farms 2 and 3 (Fig. 3), but not on Farm 1. A total of 166 wild birds (36 on Farm 1, 91 on Farm 2 and 39 on Farm 3), representing 20 different species, was captured. Table 2 summarises the species captured on each poultry farm, along with species richness, apparent abundance, and Shannon's diversity index values. An average of 12.8 birds was captured per sampling day (range: 1 to 40). The number of sampled birds per day was marginally different among the three farms $(H=4.75, d f=2, p=0.093)$. All the captured species are considered to be of least concern by the International Union for the Conservation of Nature, except for the saw-billed hermit (Ramphodon naevius), which is considered to be near threatened. 


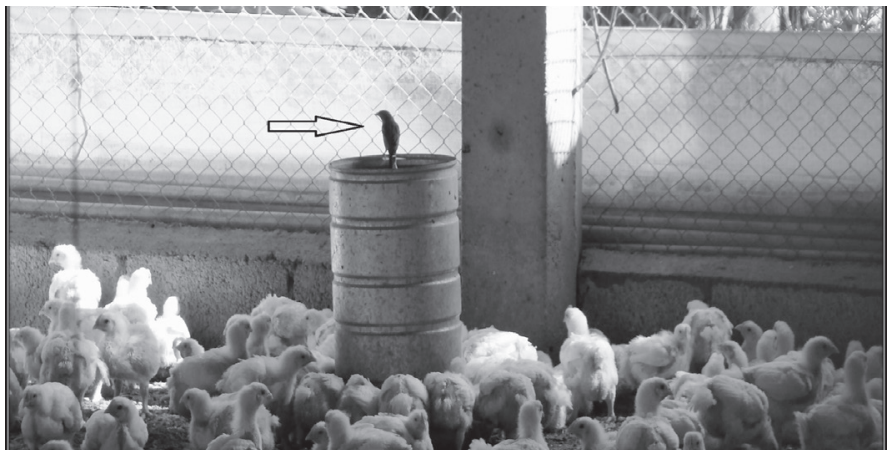

Figure 3 - A free-ranging passerine rests on a feeder for broiler chickens at Farm 2 . This proximity between wild and domestic birds represents a critical interface for the transmission of pathogens (arrow).
The three most common species were Passer domesticus (33\%), Sicalis flaveola (22\%) and Columbina talpacoti (15\%), as shown in Table 3. Twenty birds presented feather mites and either a poor or normal body condition: one of these birds was captured on Farm 1 (5\%), thirteen on Farm 2 (65\%), and six on Farm 3 (30\%). These birds accounted for $21.8 \%$ of $P$. domesticus caught (12/55), but only $8.1 \%$ of S. flaveola (3/37) and $4 \%$ of C. talpacoti (1/25).

All the PCR tests for the detection of the evaluated viruses and $\mathrm{Mg}$ were run in duplicate and were negative.
Table 2 - Results of the captured species according to species richness and Shannon's diversity index for wild birds captured near breeder, egglaying and broiler poultry farms.

\begin{tabular}{|c|c|c|c|c|}
\hline & Farm 1 & Farm 2 & Farm 3 & Total \\
\hline \multicolumn{5}{|l|}{ Trochilidae } \\
\hline Chlorostilbon aureoventris & - & $1[1 \%]$ & - & $1[1 \%]$ \\
\hline Ramphodon naevius & $1[3 \%]$ & - & - & $1[1 \%]$ \\
\hline \multicolumn{5}{|l|}{ Columbidae } \\
\hline Columbina talpacoti & $4[11 \%]$ & $\begin{array}{c}19 \\
{[21 \%]}\end{array}$ & $2[5 \%]$ & 25 [15\%] \\
\hline \multicolumn{5}{|l|}{ Emberizidae } \\
\hline Zonotrichia capensis & $3[8 \%]$ & $4[4 \%]$ & $1[3 \%]$ & $8[5 \%]$ \\
\hline \multicolumn{5}{|l|}{ Furnariidae } \\
\hline Furnarius rufus & - & $4[4 \%]$ & $2[5 \%]$ & $6[4 \%]$ \\
\hline \multicolumn{5}{|l|}{ Icteridae } \\
\hline Chrysomus ruficapillus & - & 8 [9\%] & $1[3 \%]$ & $9[5 \%]$ \\
\hline Molothrus bonariensis & - & $7[8 \%]$ & - & $7[4 \%]$ \\
\hline \multicolumn{5}{|l|}{ Parulidae } \\
\hline Basileuterus culicivorus & $1[3 \%]$ & - & - & $1[1 \%]$ \\
\hline \multicolumn{5}{|l|}{ Passeridae } \\
\hline Passer domesticus & 20 [56\%] & $4[4 \%]$ & 31 [79\%] & $55[33 \%]$ \\
\hline \multicolumn{5}{|l|}{ Thraupidae } \\
\hline Sicalis flaveola & - & $37[41 \%]$ & - & 37 [22\%] \\
\hline Tachyphonus coronatus & $1[3 \%]$ & - & - & 1 [1\%] \\
\hline Thraupis sayaca & $1[3 \%]$ & - & - & $1[1 \%]$ \\
\hline \multicolumn{5}{|l|}{ Troglotydae } \\
\hline Troglodytes aedon & - & - & $1[3 \%]$ & $1[1 \%]$ \\
\hline \multicolumn{5}{|l|}{ Turdidae } \\
\hline Turdus amaurochalinus & $2[6 \%]$ & $1[1 \%]$ & $1[3 \%]$ & $4[2 \%]$ \\
\hline Turdus flavipes & - & $1[1 \%]$ & - & $1[1 \%]$ \\
\hline Turdus rufiventris & - & $1[1 \%]$ & - & $1[1 \%]$ \\
\hline \multicolumn{5}{|l|}{ Tyrannidae } \\
\hline Elaenia flavogaster & - & $2[2 \%]$ & - & $2[1 \%]$ \\
\hline Fluvicola nengeta & - & $1[1 \%]$ & - & $1[1 \%]$ \\
\hline Pitangus sulphuratus & $1[3 \%]$ & $1[1 \%]$ & - & $2[1 \%]$ \\
\hline Todirostrum cinereum & $2[6 \%]$ & - & - & $2[1 \%]$ \\
\hline Total number of individuals ( $\mathrm{N}$ ) & 36 & 91 & 39 & 166 \\
\hline Sampling effort (days) & 4 & 4 & 5 & 13 \\
\hline Apparent abundance (N / Sampling effort) & 9.0 & 22.75 & 7.8 & 12.77 \\
\hline Species richness $(S)$ & 10 & 14 & 7 & 20 \\
\hline Species richness / total individuals (S / N) & 0.278 & 0.153 & 0.179 & 0.120 \\
\hline Shannon diversity index $\left(H^{\prime}\right)$ & 1.60 & 1.90 & 0.86 & 2.07 \\
\hline
\end{tabular}

\section{DISCUSSION}

\section{Species composition of mist net- captured birds frequenting poultry farms}

Three species were predominant in the captures using the mist nets placed on the studied farms: house sparrows (Passer domesticus), saffron finches (Sicalis flaveola), and ruddy ground-doves (Columbina talpacoti). Together, these three species accounted for $70 \%$ of the total number of captured birds. The overall diversity and equitability indexes were quite low, as expected because the studied poultry farms were located in heavily human-impacted landscapes not far from urban centres, where habitat diversity and heterogeneity are relatively poor compared with the natural areas of Atlantic rainforest (Dantas \& Rocha 2005).

A predominance of synanthropic birds in areas of poultry farms has also been observed in other studies conducted in southern Brazil. Scherer et al. (2011) reported that $S$. flaveola and C. talpacoti were the most frequent species on two broiler farms, while Fontana et al. (2011) used voice playbacks and determined $P$. domesticus and rock doves (Columba livia) as the most frequent species in an urban area. Species such as $P$. domesticus and $C$. livia are classic examples of invasive urban exploiter species, and these birds are known to be predominant in avian communities in urban and rural areas worldwide (Marzluff, 2001). The relationship between the composition and poor diversity of 
Table 3 - Total number of individuals, apparent abundance, percentage of birds with a poor or normal body condition, and percentage of birds presenting with feather mites for the three dominant species (Columbina talpacoti, Passer domesticus, and Sicalis flaveola).

\begin{tabular}{|c|c|c|c|c|}
\hline & Farm 1 & Farm 2 & Farm 3 & $\mathrm{P}$ \\
\hline \multicolumn{5}{|c|}{ Total number of individuals ( $\mathrm{N}$ ) } \\
\hline C. talpacoti & 4 & 19 & 2 & 0.054 \\
\hline P. domesticus & 20 & 4 & 31 & $<0.001$ \\
\hline S. flaveola & - & 37 & - & $<0.001$ \\
\hline \multicolumn{5}{|c|}{ Apparent abundance ( $\mathrm{N}$ / sampling day) } \\
\hline C. talpacoti & 1 & 4.75 & 0.4 & 0.394 \\
\hline P. domesticus & 5 & 1 & 6.2 & 0.160 \\
\hline S. flaveola & - & 9.25 & - & 0.019 \\
\hline \multicolumn{5}{|c|}{ Percentage with a poor or normal body condition } \\
\hline C. talpacoti & $0 \%(0 / 4)$ & $23 \%(3 / 13)$ & $50 \%(1 / 2)$ & nt \\
\hline P. domesticus & $0 \%(0 / 20)$ & $25 \%(1 / 4)$ & $60 \%(18 / 30)$ & $<0.001$ \\
\hline S. flaveola & - & $15 \%(4 / 26)$ & - & nt \\
\hline \multicolumn{5}{|c|}{ Percentage with feather mites } \\
\hline C. talpacoti & $0 \%(0 / 3)$ & $15 \%(2 / 13)$ & $0 \%(0 / 2)$ & nt \\
\hline P. domesticus & $50 \%(7 / 14)$ & $0 \%(0 / 4)$ & $60 \%(18 / 30)$ & 0.077 \\
\hline S. flaveola & - & $50 \%(10 / 20)$ & - & nt \\
\hline
\end{tabular}

$\mathrm{nt}=$ not tested due to an insufficient sample size.

avian communities in areas near poultry farms may be associated with lack of biosecurity practices; presence of birds in the feeders (Fig. 1) or feeding from grains during transport within the poultry farms; loss of habitat quality in urban and agricultural areas; reduction in plot sizes; irregular occupation associated with high density housing; a poor diversity of trees planted for street ornamentation; and/or vegetation damage caused by pedestrians (Toledo et al., 2011).

Despite being located in the same region and sharing the same general climate and landscape characteristics, the studied farms presented considerably different avifauna composition. Compared with the other two farms, Farm 1 applied considerably stricter biosecurity measures, including netting, which effectively prevented the entry of free-ranging birds into the production facilities and was more isolated from fragments of native vegetation. This area showed moderate abundance, but poor diversity of captured birds, with a predominance of $P$. domesticus. Farm 2 had poor biosecurity, but it was surrounded by a mixture of eucalyptus and pine trees, and had a considerably different avifauna composition that was more diverse than that of the other two farms. Farm 2 was co-dominated by S. flaveola and C. talpacoti, while $P$. domesticus exhibited a much lower apparent abundance. Farm 3 also had poor biosecurity, and its avifauna was strongly dominated by P. domesticus, displaying the poorest diversity.

The presence of $P$. domesticus is sufficient to threaten and repel other birds, which tend to decline in abundance as the population of this species increases (Sick, 1997). The dominance of $P$. domesticus on Farms 1 and 3 is likely associated with its great ability to colonise and breed in both urban and rural areas (Szabó et al., 2002), while the poor diversity and equitability of the avian communities on those farms is most likely the result of this species' aggressive behaviour.

S. flaveola is popular among illegal animal dealers in Brazil and is commonly held captive in rural households (RENCTAS, 2002). When recovered by local authorities, these birds are often released back into the wild (Marcondes-Machado, 1988) in wild-life release areas, such as Barragem Ponte Nova (IBAMA 2006). It is our belief that the high apparent abundance of this species on Farm 2 (the species was not observed at the other two farms) was due to the farm's proximity to this bird's release area and potentially to the fact that the gregarious behaviour and aggressive territorialism of S. flaveola towards $P$. domesticus (Sick, 1997) may have reduced the presence of $P$. domesticus at Farm 2 .

Co-dominance of $S$. flaveola with C. talpacoti was also observed on the poultry farms studied by Scherer et al. (2011), suggesting a pattern of peaceful codominance between these species. It is hypothesised that the exclusion of $P$. domesticus produces more favourable conditions for the expansion of $C$. talpacoti populations (and possibly of other species as well, considering that Farm 2 presented the highest diversity and equitability indexes). Future studies will be useful to clarify whether these competitive exclusions do in fact occur and how human impacts may affect these interactions. 


\section{Health status of the free-ranging birds captured on the poultry farms}

The proportion of birds in poor or regular body condition was higher in Farm 3 (63\%) compared with Farm 2 (19\%) and Farm 1 (0\%). This pattern may also be related to the fact that the sampling on Farms 2 and 3 occurred during the winter; however, this may not fully explain this finding, and other environmental or habitat quality factors may also have been involved.

AIV, NDV and Mg are known to occur sporadically in Brazil (Bueno et al., 1977; MS 2004; MAPA 2011). AIV was first isolated in Brazil in 1980 from the faeces of white-faced whistling ducks (Dendrocygna viduata) and exotic birds in Rio de Janeiro state (Salcedo-Chaves 1980). No influenza outbreaks have been directly linked with transmission from wild birds in the Brazil. However, the influenza virus A was isolated from as much as $27 \%$ of Columbiformes and Passeriformes in urban and rural areas of São Paulo state (Kawamoto et al., 2005).

NDV was first identified in Brazil in 1953 in the states of Pará and Amapá, and was introduced to these locations via the importation of contaminated carcasses from the United States (Santos, 1954). Since then, the disease has been sporadically reported. Indeed, the latest outbreak occurred in 2006 in a small group of homebred chickens in Rio Grande do Sul state (MAPA, 2011). Serological studies identified zero or generally low seroprevalence among wild and zoo birds (Oliveira-Junior et al., 2003). Three out of 103 P. domesticus (2.9\%) captured near breeder poultry farms in the state of Pernambuco exhibited low antibody titres for NDV. It was concluded that these birds had consumed vaccines in the drinking water, indicating the close proximity and potential exchange of pathogens between these wild birds and domestic flocks (Silva et al., 2006).

The first identification of $\mathrm{Mg}$ causing chronic respiratory disease in poultry in Brazil was reported in São Paulo state in 1956 (Ferreira et al., 2009). No Mg outbreaks have been reported in wild birds. However, this disease has been frequently observed in domestic birds (Bueno et al., 1977), and Mg may be detected in as many as $52 \%$ of the Psittacidae admitted into wildlife rehabilitation centres (Gomes et al., 2010; Destro et al., 2012), demonstrating the circulation of this pathogen in wild birds. Experimentally-infected $P$. domesticus are known to effectively shed Mg, while presenting relatively mild clinical symptoms (Dhondt et al., 2008). Mg strains may vary greatly in virulence and infectivity (Ley, 2003), and synanthropic birds are potential vectors and temporary biological carriers of this pathogen, and display different immune responses compared with chickens (Gharaibeh \& Hailat 2011).

In this study, the PCR results for all 166 wild birds captured within close proximity to poultry farms were negative, despite the tests having been conducted in duplicate and the use of positive controls. The diagnostic methods employed in this study are known to have high sensitivity (Nascimento et al., 1991; Pang et al., 2002; Poddar 2002) and are therefore likely to reflect a true absence of these pathogens at the time of sampling.

It is well-established that one of the most consistent effects of increasing human settlement is the increase of non-native bird populations, a pattern that is consistent throughout the world in a variety of habitats and is independent of the methods or duration of studies (Marzluff, 2001). The animal industry has developed increasingly productive and intensive practices and, as a result, the introduction and spread of pathogens via errant contact with wildlife or through the global trading of animals and products has increased (Karesh et al., 2012).

Our results demonstrate that free-ranging avian communities may be comprised of a few dominant species, such as $P$. domesticus or S. flaveola, which are known to carry and transmit disease. Moreover, these dominant synanthropic birds may provide an epidemiological connection, transmitting pathogens from domestic poultry to endangered birds in nearby forest fragments (Gondim et al., 2010; Lawson et al., 2010; Fontana et al., 2011; Scherer et al., 2011; Tramer, 1969).

The ability of these birds to carry and transmit pathogens varies according to host susceptibility, clinical signs, shedding rates, and the characteristics of the interface between domestic and wild birds (Brown et al., 2009; Woodford, 2009). The free-ranging birds found inside poultry facilities are most frequently observed in positions above the other birds, defecating and eliminating respiratory secretions in their food or water or on the chickens themselves, thereby facilitating pathogen transmission (Brown et al., 2009). Species such as $P$. domesticus are particularly problematic because their cosmopolitan distribution makes them a worldwide pathogen reservoir and source of infection of humans and domestic and wild birds (Gondim et al., 2010). Additionally, if preyed upon, these synanthropic birds may transmit pathogens to susceptible mammals, such as cats and pigs (Kuiken et al., 2004; Lipatov et al., 2008). 
Although no evidence of AIV, NDV or Mg infection was observed in the studied birds, our findings demonstrate that differences in the environmental characteristics and biosecurity practices influence the wild bird community near poultry farms, which in turn may affect the health status of these synanthropic birds and strengthen their role in the transmission of pathogens to and from domestic poultry. The increasing and profound infiltration of human activities, including animal production, into the few remnant areas of the Atlantic forest may pose a critical threat to the conservation of this threatened biome, as well as public health and economic risks to the poultry industry. Therefore, these areas should be intensively and carefully monitored and managed through longterm epidemiological monitoring of the domestic-wild bird interface.

\section{ACKNOWLEDGMENTS}

The authors are grateful to the Wildlife Conservation Society for financial support to this project, and to Granja Kunitomo and Avicola Paulista.

\section{REFERENCES}

Brown JD, Stallknecht DE, Berghaus RD, Swayne DE. Infectious and lethal doses of H5N1 highly pathogenic avian influenza virus for house sparrow (Passer domesticus) and rock pigeons (Columbia livia). Journal of Veteterinary Diagnostic Investigation 2009;21:437-445

Bueno RC, Baquer SR, Nakano M. Doenças de aves em São Paulo (análise de 24217 casos). Arquivos do Instituto Biológico 1977;29:231-270.

Cardoso ALSP, Tessari ENC, Castro AGM, Kanashiro AMI, Stoppa GFZ. Monitoria sorológica da micoplasmose em plantéis de aves reprodutoras no Brasil através do teste de soroaglutinação rápida. Arquivos do Instituto Biológico 2006;73:23-26

CEPAGRI. Centro de Pesquisas Meteorológicas e Climáticas aplicadas à Agricultura. Campinas; 2012. Available from: www.cepagri.unicamp. br.

Dantas TB, Rocha PLB. Corredores ecológicos - uma tentativa para reverter ou minimizar a fragmentação florestal e seus processos associados. In: Franke CR, Rocha PLB, Klein W, Gomes SL, editors. Salvador: Mata Atlântica e biodiversidade. Salvador: Edufba; 2005. p.165-189.

Dean W. With broadax and firebrand: the destruction of the Brazilian Atlantic forest. Berkeley: University of California Press; 1995. 504p.

Destro GFG, Pimentel TL, Sabaini RM, Borges RC, Barreto R. Efforts to Combat Wild Animals Trafficking in Brazil. In: Lameed GA, editor. Biodiversity enrichment in a diverse world. Rijeka: InTech; 2012. p. 42435.

Dhondt AA, Dhondt KV, McCleery BV. Comparative infectiousness of three passerine bird species after experimental inoculation with Mycoplasma gallisepticum. Avian Pathology 2008;37:635-640.

Ferreira AJP, Revolledo L, Ferreira CSA. Colibacilose. In: Revolledo L, Ferreira AJP, editors. Patologia aviária. Barueri: Editora Manole; 2009. p.67-74.
Fontana CS, Burger MI, Magnusson WE. Bird diversity in a subtropical South-American city: effects of noise levels, arborisation and human population density. Urban Ecosystem 2011;14:341-360.

Gharaibeh S, Hailat A. Mycoplasma gallisepticum experimental infection and tissue distribution in chickens, sparrows and pigeons. Avian Pathology 2011;40:349-354.

Gomes AM, Costa LL, Vilela DAR, Marques MVR, Carvalhaes AG, Marin SY, et al. Detection of Mycoplasma gallisepticum in dead captive psittacines in Belo Horizonte, Brazil. Brazilian Journal of Poultry Science 2010;12:75-78

Gondim LAQ, Abe-Sandes K, Uzêda RS, Silva MSA, Santos SL, Mota RA, et al. Toxoplasma gondii and Neospora caninum in sparrows (Passer domesticus) in the Northeast of Brazil. Veterinary Parasitology 2010;168:121-124.

IBAMA - Instituto Brasileiro do Meio Ambiente e dos Recursos Renováveis Manual de anilhamento de aves silvestres. $2^{a}$ ed. Brasília (DF) IBAMA; 1994

IBAMA - Instituto Brasileiro do Meio Ambiente e dos Recursos Renováveis Brasília; 2006. Available from: http://www.ibama.gov.br.

Jones J. Provisional profile for Newcastle Disease. Veterinary Surveillance Strategy; 2009. Available from: http://www.defra.gov.uk/animalh/ diseases/vetsurveillance/profiles/nd-fullprofile.pdf.

Karesh WB, Dobson A, Lloyd-Smith JO, Lubroth J, Dixon MA, Bennett M, et al. Ecology of zoonoses: natural and unnatural histories. Lancet 2012:380:1936-1945

Kawamoto AHN, Mancini DAP, Pereira LE, Cianciarullo AM, Cruz AS, Dias ALF, et al. Investigation of influenza in migrating birds, the primordial reservoir and transmitters of influenza in Brazil. Brazilian Journal of Microbiology 2005;36:88-93.

Kleven SH. Mycoplasmosis. In: Saif YM, Fadly AM, Glisson JR, McDougald LR, Nolan LK, Swayne DE, editors. Diseases of poultry. Ames: Blackwell Publishing; 2008. p. 805-864.

Kuiken T, Rimmelzwaan G, van Riel D, van Amerongen G, Baars M, Fouchier R, Osterhaus A. Avian H5N1 influenza in cats. Science 2004;306(5694):241

Lawson B, Howard T, Kirkwood JK, Macgregor SK, Perkins M, Robinson RA, et al. Epidemiology of Salmonellosis in garden birds in england and wales, 1993 to 2003. EcoHealth 2010;7:294-306.

Ley DH. Mycoplasma gallisepticum infection. In: Saif YM, Barnes HJ, Glisson JR, Fadly AM, McDougald LR, Swayne DE, editors. Diseases of poultry. Ames: Blackwell Publishing; 2003. p.722-744.

Lipatov AS, Kwon YK, Sarmento LV, Lager KM, Spackman E, Suarez DL, et al. Domestic pigs have low susceptibility to H5N1 highly pathogenic avian influenza viruses. PLoS Pathogens 2008;4:e1000102

MAPA - Ministério da Agricultura, Pecuária e Abastecimento. Brasília (DF); 2011. Available from: http://www.agricultura.gov.br/2011.

Marcondes-Machado LO. Experiência de repovoamento com Sicalis flaveola brasiliensis (Gmelin, 1789) (Passeriformes, Emberizidae) em área destinada à pecuária leiteira. Revista Brasileira de Zoologia 1988;5:193200 .

Marzluff JM. Avian ecology and conservation in an urbanizing world. In: Marzluff JM, Bowman R, Donnelly R, Norweel MA, editors. Worldwide urbanization and its effects on birds. Norwell: Kluwer Academic Publishers; 2001. p.19-43.

MS - Ministério da Saúde. Brasília (DF); 2004. Available from: http://www. saude.gov.br/2004. 


\section{Southeastern Brazil}

Myers N, Mittermeier RA, Mittermeier CG, Fonseca GAB, Kent J. Biodiversity hotspots for conservation priorities. Nature 2000;403:853-858.

Nascimento ER, Yamamoto R, Herrick KR, Tait RC. Polymerase chain reaction for detection of Mycoplasma gallisepticum. Avian Diseases 1991;35:62-69.

RENCTAS - Rede Nacional de Combate ao Tráfico de Animais Silvestre. 2002. Available from: http://www.renctas.org.br.

Oliveira Jr. JG, Portz C, Loureiro BO, Schiavo PA, Fedullo LPL, Mazur C, et al. Serology for the Newcastle disease virus in non-vaccinated birds in the State of Rio de Janeiro, Brazil. Ciência Rural 2003;33:381-383.

Pang $Y$, Wang $H$, Girshick T, Xie Z. Development and application of a multiplex polymerase chain reaction for avian respiratory agents. Avian Diseases 2002;46:691-699.

Poddar SK. Influenza virus types and subtypes detection by single step single tube multiplex reverse transcription-polymerase chain reaction (RT-PCR) and agarose gel electrophoresis. Journal of Virological Methods 2002;99:63-70

Salcedo-Chaves JR. Ocorrência de influenza em aves selvagens e pássaros ornamentais no Rio de Janeiro [dissertation]. Rio de Janeiro (RJ): Universidade do Rio de Janeiro; 1980.

Santos JA. A ocorrência da doença de Newcastle no Brasil (nota prévia). Revista de Produção Animal 1954;1:5-12.

Scherer AL, Scherer JF, Petry MV, Sander M. Occurrence and interaction of wild birds at poultry houses in Southern Brazil. Revista Brasileira de Ornitologia 2011;19:74-79.

Sick H. Ornitologia brasileira. Rio de Janeiro: Nova Fronteira; 1997. 912p
Silva JSA, Mota RA, Vilela SMO, Doretto JL, Pinheiro JJW, Silva LBG. Newcastle disease virus infection in sparrows (Passer domesticus, Linnaeus, 1758) captured in poultry farms of the agreste region of the state of Pernambuco. Brazilian Journal of Poultry Science 2006;8:125129

SOS Mata Atlântica. São Paulo; 2012. Available from: https://www.sosma. org.br/SOS Atlantic Forest.

Tabarelli M, Pinto LP, Silva JMC, Hirota MM, Bede LC. Desafios e oportunidades para a conservação da biodiversidade na Mata Atlântica brasileira. Megadiversidade 2005;1:132-138.

Toledo MCB, Donatelli RJ, Batista GT. Relation between green spaces and bird community structure in an urban area in Southeast Brazil. Urban Ecology 2011;15:111-131.

Tramer EJ. Bird species diversity: components of Shannon's formula. Ecology 1969;50:927-929

UBABEF - União Brasileira de Avicultura e Exportadores de Frangos. São Paulo; 2011. Available from: http://www.brazilianchicken.com.br/ home/conhecaubabef.

Webby RJ, Webster RG. Are we ready for pandemic influenza? Science 2003;302:1519-1522

WHO - World Health Organization. Genebra; 2003. Available from: http:// www.who.int/whr/2003/en

Woodford $\mathrm{MH}$. Veterinary aspects of ecological monitoring: the natural history of emerging infectious diseases of humans, domestic animals and wildlife. Tropical Animal Health and Production 2009;41:10231033 